\title{
Intercellular signalling within vascular cells under high D-glucose involves free radical-triggered tyrosine kinase activation
}

\author{
G. Schaeffer ${ }^{1}$, S. Levak-Frank ${ }^{1}$, M. M. Spitaler ${ }^{1}$, E. Fleischhacker ${ }^{1}$, V. E. Esenabhalu ${ }^{1}$, A. H. Wagner ${ }^{2}$, \\ M. Hecker ${ }^{2}$, W. F. Graier ${ }^{1}$ \\ ${ }^{1}$ Department of Medical Biochemistry and Medical Molecular Biology, University of Graz, Graz, Austria \\ 2 Department of Cardiovascular Physiology, University of Goettingen, Goettingen, Germany
}

\begin{abstract}
Aims/hypothesis. Diabetes mellitus is associated with endothelial dysfunction in human arteries due to the release of superoxide anions $\left(\mathrm{O}_{2}^{-}\right)$that was found to occur predominantly in smooth muscle cells (SMC). This study was designed to elucidate the impact of high glucose concentration mediated radical production in SMC on EC. Pre-treatment of vascular SMC with increased D-glucose enhanced release of $\mathrm{O}_{2}{ }^{-}$. Methods. Microscope-based analyses of intracellular free $\mathrm{Ca}^{2+}$ concentration (fura-2), immunohistochemistry (f-actin) and tyrosine kinase activity were performed. Furthermore, RT-PCR and Western blots were carried out.

Results. Interaction of EC with SMC pre-exposed to high glucose concentration yielded changes in endothelial $\mathrm{Ca}^{2+}$ signalling and polymerization of $\mathrm{f}$-actin in a concentration-dependent and superoxide dismutase (SOD) sensitive manner. This interaction activated endothelial tyrosine kinase(s) but not NFKB and AP-1,
\end{abstract}

while SOD prevented tyrosine kinase stimulation but facilitated NFKB and AP-1 activation. Erbstatin, herbimycin A and the src family specific kinase inhibitor PP-1 but not the protein kinase $\mathrm{C}$ inhibitor GF109203X prevented changes in endothelial $\mathrm{Ca}^{2+}$ signalling and cytoskeleton organization induced by pre-exposure of SMC to high glucose concentration. Adenovirus-mediated expression of kinase-inactive c-src blunted the effect of pre-exposure of SMC to high glucose concentration on EC.

Conclusions/interpretation. These data suggest that SMC-derived $\mathrm{O}_{2}{ }^{-}$alter endothelial cytoskeleton organization and $\mathrm{Ca}^{2+}$ signalling via activation of c-src. The activation of c-src by SMC-derived radicals is a new concept of the mechanisms underlying vascular dysfunction in diabetes. [Diabetologia (2003) 46:773-783]

Keywords AP-1, cytoskeleton, diabetes, hyperglycaemia, $\mathrm{Ca}^{2+}, \mathrm{NF \kappa B}$, src, superoxide anion.
Received: 3 December 2002 / Revised: 14 January 2003

Published online: 13 June 2003

C Springer-Verlag 2003

Corresponding author: W. F. Graier, Department of Medical Biochemistry and Medical Molecular Biology, University of Graz, Harrachgasse 21/III, 8010 Graz, Austria

E-mail: wolfgang.graier@uni-graz.ac.at

Abbreviations: PP-1, 4-amino-5-(4-methylphenyl)-7-(t-butyl)pyrazolo[3,4-d]pyrimidine; GF 109203X, 2-[1-(3-dimethylaminopropyl)-1H-indol-3-yl]-3-(1H-indol-3-yl)-maleimide; AP-1, activator protein-1; DMEM, Dulbecco's Minimal Essential Medium; EC, endothelial cells; $\left[\mathrm{Ca}^{2+}\right]$, intracellular free $\mathrm{Ca}^{2+}$ concentration; NFאB, nucear factor $\kappa \mathrm{B}$; SMC, smooth muscle cells; $\mathrm{O}_{2}^{-}$, superoxide anions; $\mathrm{SOD}$, superoxide dismutase.
In the genesis of diabetes-induced cardiovascular dysfunction a concerted malfunction of many cells like endothelial cells (EC), smooth muscle cells (SMC), macrophages and platelets is involved $[1,2,3,4,5]$. Therefore, the impact of hyperglycaemia on these cells and the mechanisms of the fatal interaction of blood cells with the vascular wall in diabetes have been extensively investigated. However, the cellular interplay between vascular cells under diabetic conditions has been rarely studied so far.

Recently, we have described that the increased release of superoxide anions $\left(\mathrm{O}_{2}^{-}\right)$from uterine arteries of diabetic patients was due to enhanced $\mathrm{O}_{2}{ }^{-}$production in SMC rather than in EC [6]. Although these 
data might be related to this particular type of artery and are in contradiction with reports in murine models [7], it is unclear whether, and if so, how vascular SMC affect EC during diabetes. Such smooth muscle originated modulation of EC function adds to our recent paradigm in which vascular dysfunction in diabetes (and many other diseases) is thought to occur initially in EC that, in turn, affects the vascular SMC $[1,8]$.

Hyperglycaemia has been clearly shown to initiate activation of protein kinase $\mathrm{C}$ that is thought to be crucially involved in the endothelial dysfunction under hyperglycaemic conditions [9]. Besides protein kinase $\mathrm{C}$, the modulation of a number of additional signal transduction pathways has been reported in hyperglycaemia [7]. Thus, it seems interesting to assess the endothelial target(s) of smooth muscle-derived factors in hyperglycaemia.

In this study we used a co-culture model of EC and SMC in order to elucidate how vascular SMC affect EC in the presence of high glucose concentrations. Notably, the signal molecule(s) of the cellular interplay between the two cell types of the vascular wall, the mechanism of EC manipulation and the consequences thereof were assessed using short time cultured endothelial and smooth muscle cells from porcine aortae.

\section{Materials and methods}

Materials. Foetal calf serum was from PAA Laboratories, Linz, Austria and cell culture chemicals were purchased at Life Technologies, Vienna, Austria. Six-well plates and inserts were purchased at BD Biosciences, Vienna, Austria. Fluorescent dyes were obtained from Molecular Probes, Leiden, Netherlands. DNase I was from Promega (Mannheim, Germany), reverse transcriptase from Invitrogen (Vienna, Austria) and DyNAzyme DNA II polymerase was obtained from Finnzymes (Vienna, Austria). Western blot and radioactive chemicals were from Amersham Biosciences, Vienna, Austria. Antibodies were obtained from Biomol, Hamburg, Germany. Erbstatin analog, herbimycin A, 4-amino-5-(4-methylphenyl)-7-( $t$-butyl)pyrazolo[3,4-d]pyrimidine (PP-1) and 2-[1-(3-dimethylaminopropyl)1H-indol-3-yl]-3-(1H-indol-3-yl)-maleimide (GF109203X) were purchased at Calbiochem-Novabiochem (Bad Soden, Germany).

Cell Culture. Endothelial cells (EC) were isolated from porcine aortae [10]. Fresh porcine aortae were incubated at $37^{\circ} \mathrm{C}$ with 200 U/ml collagenase (type II) in Dulbecco's Minimal Essential Medium (DMEM) plus 1\% MEM essential amino acids, 1\% MEM non-essential amino acids, 1\% MEM vitamins and $1 \mathrm{mg} / \mathrm{ml}$ trypsin inhibitor type I. Isolated EC were cultured in Opti-MEM containing 3\% FCS. Cell culture purity was confirmed by typical cobblestone morphology and the absence of SMC $\alpha$-actin. Experiments were carried out with cells from 1 st passage.

Porcine aortic smooth muscle cells (SMC) were isolated using the explant technique [6]. Endothelium and connective tissue were removed from $1 \mathrm{~cm}^{2}$ pieces of the porcine aorta that was washed with cold phosphate buffered saline (in mmol/l: $137 \mathrm{NaCl}, 2.7 \mathrm{KCl}, 8 \mathrm{Na}_{2} \mathrm{HPO}_{4} \times 2 \mathrm{H}_{2} \mathrm{O}, 1.5 \mathrm{KH}_{2} \mathrm{PO}_{4}$; $\mathrm{pH} 7.4$; $\mathrm{PBS})$. The remaining smooth muscle layer was cut into small pieces, covered with a sterile glass cover slip and cultured in Opti-MEM containing 3\% foetal calf serum. For experiments, cells from the 1 st passage were used. Cell culture purity was confirmed by positive $\alpha$-actin staining.

Cell interaction experiments. We cultured SMC in six-well plates while EC were cultured on inserts in separate six-well plates. After reaching confluence, SMC were treated with DMEM containing the D-glucose concentration indicated. After $24 \mathrm{~h}$, the SMC were washed twice with DMEM and the inserts with the EC were transferred into the smooth muscle containing six-well plates. Cell interaction was allowed in DMEM for the indicated time (Fig. 1).

$\mathrm{Ca}^{2+}$ measurement. Intracellular free $\mathrm{Ca}^{2+}$ concentration $\left(\left[\mathrm{Ca}^{2+}\right]_{\mathrm{i}}\right)$ was measured using fura- 2 as previously described [11]. Experiments were carried out in Hepes-buffered solution (HBS) with or without $2.5 \mathrm{mmol} / \mathrm{l} \mathrm{CaCl}_{2}$ (in mmol/l: 145 $\mathrm{NaCl}, 5 \mathrm{KCl}, 1 \mathrm{MgCl}_{2}, 10$ Hepes-acid; $\mathrm{pH}$ 7.4) in suspended cells in order to allow basolateral interaction of EC with SMC and methodical limits to monitor the $\mathrm{Ca}^{2+}$ signalling in confluent EC grown on inserts. Due to uncertainties of the $\left[\mathrm{Ca}^{2+}\right]_{i}$ calibration techniques, $\left[\mathrm{Ca}^{2+}\right]_{\mathrm{i}}$ is expressed as ratio $\left(\mathrm{F}_{340} / \mathrm{F}_{380}\right)$ units $(340 / 380 \mathrm{~nm}$ excitation at $510 \mathrm{~nm}$ emission).

Measurement of superoxide anions. $\mathrm{O}_{2}{ }^{-}$were photometrically measured by the reduction of ferricytochrome $\mathrm{C}$ as previously described $[10,12]$. Confluent SMC were incubated at $37^{\circ} \mathrm{C}$ in $\mathrm{Ca}^{2+}$-free PBS containing $10 \mu \mathrm{mol} / 1$ ferricytochrome $\mathrm{C}$ (horse heart type III) with or without SOD $(476 \mathrm{U} / \mathrm{ml}$; i.e. between 110 and $134 \mu \mathrm{g} / \mathrm{ml}$ protein) and the reduction of ferricytochrome $\mathrm{C}$ was followed at $550 \mathrm{~nm}$ for $30 \mathrm{~min}$. The difference of absorption between samples with or without SOD corresponds to $\mathrm{O}_{2}^{-}$-mediated reduction of ferricytochrome C. Concentrations of $\mathrm{O}_{2}^{-}$were calculated using the molar extinction coefficient of reduced ferricytochrome $\mathrm{C}(\varepsilon=21.000)$ [13].

Fluorescence microscopy. Fixation was done by incubating EC for $30 \mathrm{~min}$ at $4^{\circ} \mathrm{C}$ in PBS containing $10 \mu \mathrm{g} / \mathrm{ml}$ lysophosphatidylcholin, $3.5 \%$ formaldehyde, and $10 \mathrm{U} / \mathrm{ml}$ Bodipy $581 / 591$ phalloidine. Fluorescence was monitored at $575 \mathrm{~nm}$ excitation and $630 \mathrm{~nm}$ emission with a $40 \times$ oil immersion objective (N.A. 1.3; Nikon, Vienna, Austria) of a fluorescence microscope (Eclipse TE300, Nikon) using a cooled CCD camera (Quantix, Roper Scientific, Acton, Mass., USA). Image analysis was done using Image Pro 3.0 (Media Cybernetics, Sliver Spring, Mass., USA) [14]. Out-of-focus fluorescence was eliminated by deconvolution using the iterative constrained interation algorithm (VayTek, Fairfield, Iowa, USA).

Western Blot analysis. Confluent EC were washed twice with chilled PBS and harvested by scraping. Cell lysates were prepared in Tris-buffer (in mmol/l: 50 Tris-HCl, $150 \mathrm{NaCl}$, 1 EGTA, 1 PMSF, $1 \mathrm{Na}_{3} \mathrm{VO}_{4}, 1 \mathrm{NaF}, 0.3 \%$ sodium desoxycholate, $1 \mu \mathrm{g} / \mathrm{ml}$ aprotinin and $1 \mu \mathrm{g} / \mathrm{ml}$ leupeptin; $\mathrm{pH} 7.4$ ), followed by three cycles of freezing/thawing. Equal amounts of protein were mixed with buffer containing $20 \%$ glycerol, $5 \%$ (w/v) SDS, $0.15 \%(w / v)$ bromphenol blue, 3\% 2-mercaptoethanol and $63 \mathrm{mmol} / \mathrm{l}$ Tris- $\mathrm{HCl}(\mathrm{pH} 6.8)$, boiled for $10 \mathrm{~min}$ at $95^{\circ} \mathrm{C}$, separated on a $7.5 \%$ SDS-polyacrylamide gel and transferred onto nitrocellulose. The membrane was blocked for $3 \mathrm{~h}$ in $5 \%(\mathrm{w} / \mathrm{v})$ non-fat instant milk in PBS containing $0.05 \%$ Tween-20 and probed at $4{ }^{\circ} \mathrm{C}$ with the phosphotyrosine specific antibody 4G10 (1:1000 dilution) overnight. After washing with PBS containing $0.05 \%$ Tween 20 , the membrane was incubated for $1 \mathrm{~h}$ with horseradish peroxidase-conjugated secondary antibody (1:1000 dilution). Immunoreactivity was visualized using 
DMEM $5,15,30$ or $44 \mathrm{mmol} /$
D-glucose

DMEM

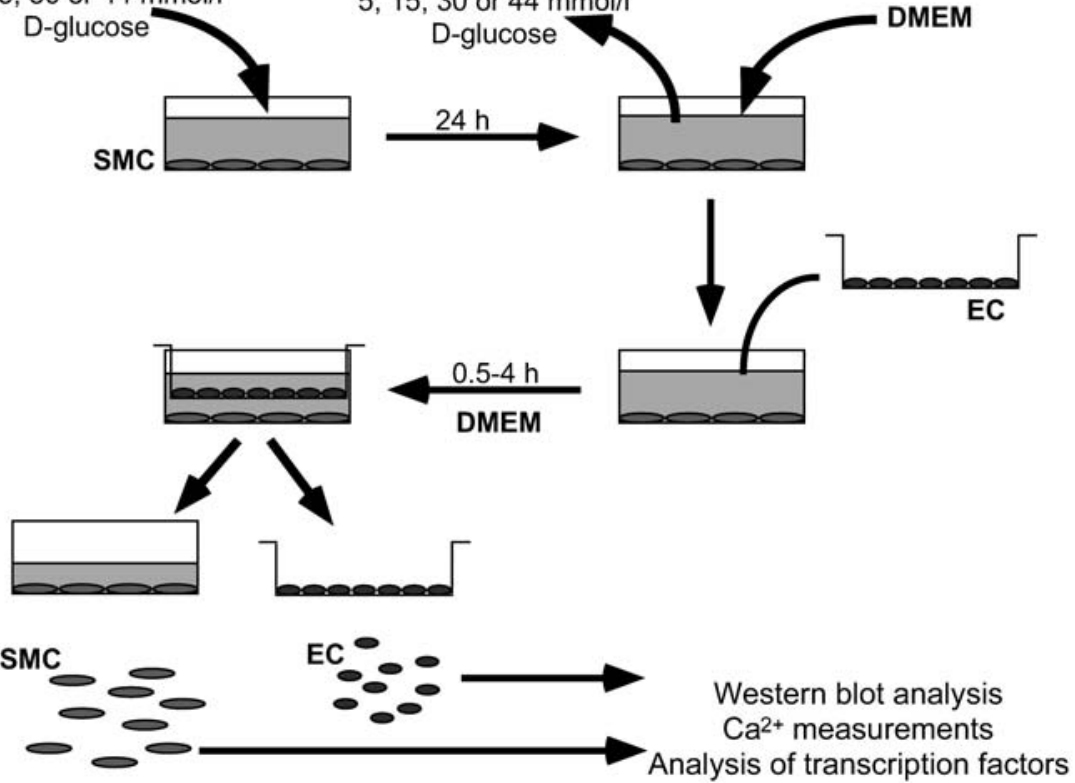

Fig. 1. Schematic presentation of the experimental protocol to study intercellular signalling between EC and SMC. Confluent SMC were incubated in DMEM containing D-glucose as indicated. After $24 \mathrm{~h}$, cells were washed three times with DMEM and inserts with EC were placed on top of the well. After the indicated interaction period, cells were harvested separately for further analysis

enhanced chemiluminescence. For additional staining, the membrane was stripped and reprobed with the $\beta$-catenin specific antibody (1:1000 dilution).

Electromobility shift assay (EMSA) for $N F \kappa B$. Cells were harvested and preparation of nuclear protein extracts, labelling and binding reaction were carried out [15]. The NFkB consensus oligonucleotide 5'-AGT TGA GGG GAC TTT CCC AGG C-3' was from Santa Cruz Biotechnology (Heidelberg, Germany). EMSAs were repeated four times and representative gels are shown.

RT-PCR for AP-1. Total endothelial RNA was isolated by using RNeasy kit (Qiagen, Vienna, Austria). $3 \mu \mathrm{g}$ thereof were treated with RQ1 RNase-free DNase I for $15 \mathrm{~min}$ at $37^{\circ} \mathrm{C}$ and subsequently used as a template for first-strand cDNA-synthesis in a $30 \mu \mathrm{l}$ reaction containing $0.5 \mu \mathrm{mol} / \mathrm{l}$ dNTPs (Roth, Graz, Austria), $15 \mathrm{U}$ RNAguard, $3.3 \mu \mathrm{M}$ random hexameric primers (Amersham Biosciences, Vienna, Austria), $10 \mu \mathrm{mol} / \mathrm{l}$ dithiothreitol and $200 \mathrm{U}$ Moloney murine leukaemia virus reverse transcriptase (Invitrogen) in first-strand buffer for $1 \mathrm{~h}$ at $37^{\circ} \mathrm{C}$. Following heat inactivation at $75^{\circ} \mathrm{C}$ for $10 \mathrm{~min}, 2.5 \mu \mathrm{l}$ of the cDNA was used as a template for PCR with specific primers for the human c-jun subunit of the transcription factor AP-1 (5'-ACG ACC TTC TAT GAC GAT GC-3' and 5'-GTG TTC TGG CTG TGC AGT TC-3') yielding a 360 bp product. $50 \mu \mathrm{l}$ PCR reaction mixture contained $0.2 \mu \mathrm{mol} / 1 \mathrm{dNTPs}, 10 \mu \mathrm{mol} / \mathrm{l}$ of each primer and 1 U DyNAzyme II DNA polymerase (Finnzymes) in PCR buffer.

Measurement of tyrosine kinase activity. Endothelial tyrosine kinase activity was measured by using a customized photometric protein tyrosine kinase kit from Calbiochem-Novabiochem

$[12,16]$. After interaction period cell lysates were obtained by sonification in chilled lysis buffer containing in mmol/l: 20 Tris, $50 \mathrm{NaCl}$, 1 EDTA, 1 EGTA, 0.2 PMSF, 0.2 mercaptoethanol plus $1 \mu \mathrm{g} / \mathrm{ml}$ pepstatin and $0.5 \mu \mathrm{g} / \mathrm{ml}$ leupeptin ( $\mathrm{pH} 7.4$ ). Phosphorylation was measured by horseradish peroxidase-labelled phosphotyrosine specific antibody and photometrically monitored at $450 \mathrm{~nm}$.

Tyrosine kinase activity was also monitored in single EC by monitoring fluorescence resonance energy transfer (FRET) using a probe for tyrosine phosphorylation of the CrkII adaptor protein (Picchu-936X) [17]. In addition, the inactive mutant Picchu-938X was used. Cells were transfected with $2 \mu \mathrm{g}$ $\mathrm{cDNA} / \mathrm{ml}$ of the respective PicchuX and FRET was monitored at $440 \mathrm{~nm}$ excitation and 480/535 $\mathrm{nm}$ emission using a beam splitter (MultSpec, Visitron, Puchheim, Germany) mounted onto the CCD camera.

Statistical analysis. Data represent the means \pm SEM. Analysis of variance was done and statistical significance was evaluated using Scheffe's post hoc F test. A $p$ value of less than 0.05 was considered statistically significant.

\section{Results}

Endothelial $\mathrm{Ca}^{2+}$ signalling. After interaction of EC with SMC pre-exposed to elevated D-glucose for $4 \mathrm{~h}$ (Fig. 1), bradykinin-initiated intracellular $\mathrm{Ca}^{2+}$ release was increased by $59 \%$ compared with EC that interacted with SMC pre-exposed to $5 \mathrm{mmol} / \mathrm{l} \mathrm{D}$-glucose (Fig. 2A; $n=33, p<0.05$ ). Furthermore, capacitative $\mathrm{Ca}^{2+}$ entry due to depletion of intracellular $\mathrm{Ca}^{2+}$ stores was increased by $170 \%$ in EC that interacted with high D-glucose pre-exposed SMC (Fig. 2A; $n=33$, $p<0.05)$. Changes in endothelial $\mathrm{Ca}^{2+}$ signalling critically depended on the concentration of D-glucose in which SMC were held for $24 \mathrm{~h}$ (Fig. 1) prior to the interaction period with EC (Fig. 2B). In contrast to pathological D-glucose concentrations, preincubation of SMC with $44 \mathrm{mmol} / \mathrm{l} \mathrm{D}$-mannitol for $24 \mathrm{~h}$ did not 


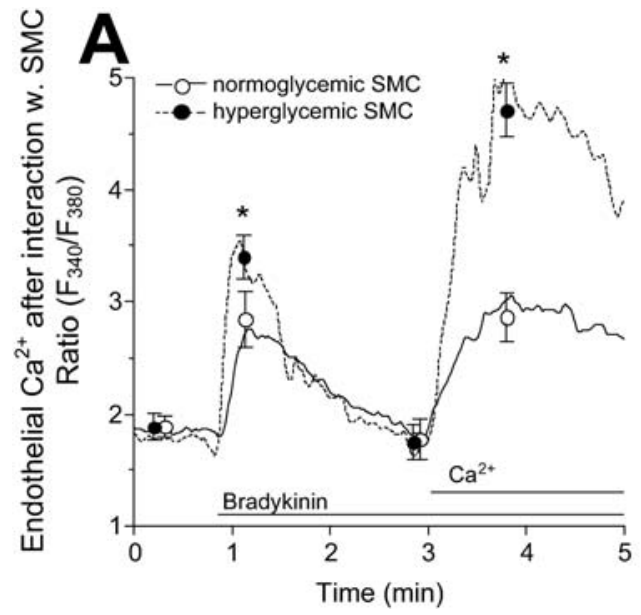

Fig. 2A, B. Effect of intercellular signalling between EC and SMC on endothelial $\mathrm{Ca}^{2+}$ signalling. After the interaction procedure shown in Fig. 1, EC were loaded with $2 \mu \mathrm{mol} / 1$ fura2/AM. $\left[\mathrm{Ca}^{2+}\right]_{\mathrm{i}}$ is expressed in ratio units $\mathrm{F}_{340} / \mathrm{F}_{380}$. (A) Representative tracings of the observed changes in endothelial $\mathrm{Ca}^{2+}$ signalling in response to $100 \mathrm{nmol} / \mathrm{l}$ bradykinin in nominal $\mathrm{Ca}^{2+}$ free solution followed by the addition of $2.5 \mathrm{mmol} / \mathrm{l} \mathrm{ex}-$ tracellular $\mathrm{Ca}^{2+}$ (i.e. capacitative $\mathrm{Ca}^{2+}$ entry). (B) Concentration response relationship between the D-glucose concentration the SMC got exposed to prior interaction $(4 \mathrm{~h}$ in the absence or presence of $200 \mathrm{U} / \mathrm{ml}$ SOD) with the EC and the changes in endothelial $\mathrm{Ca}^{2+}$ signalling in response to $100 \mathrm{nmol} / \mathrm{l}$ bradykinin in the presence of $2.5 \mathrm{mmol} / \mathrm{l}$ extracellular $\mathrm{Ca}^{2+}$. $* p<0.05$ vs endothelial $\mathrm{Ca}^{2+}$ signalling after an interaction with normoglycaemic (i.e. $5 \mathrm{mmol} / \mathrm{l} \mathrm{D}$-glucose) SMC $(n=6-33)$

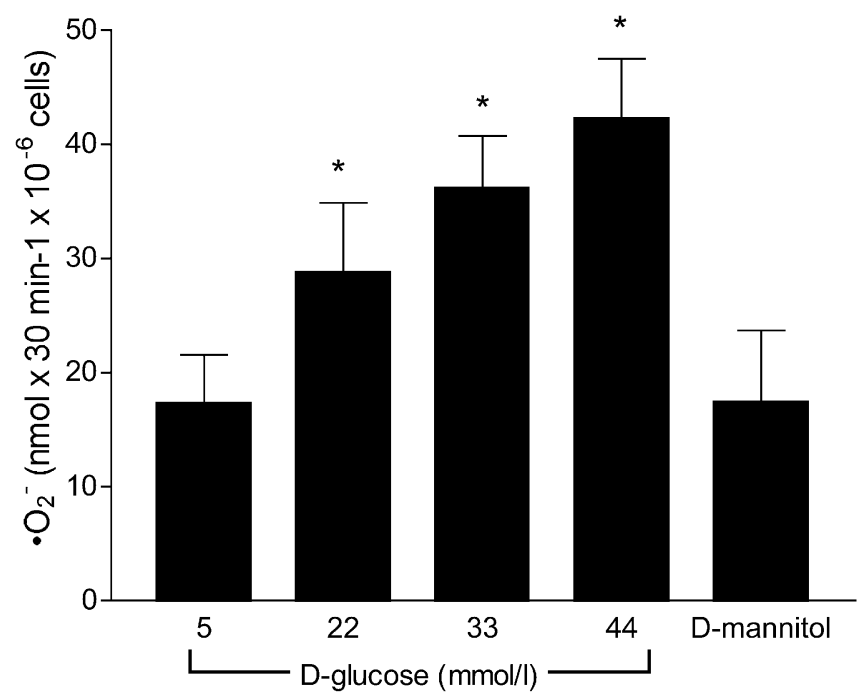

Fig. 3. Effect of elevated D-glucose on $\mathrm{O}_{2}^{-}$release from cultured SMC. Confluent SMC were incubated for $24 \mathrm{~h}$ in DMEM containing D-glucose or D-mannitol (44 mmol/l) as indicated. The release of $\mathrm{O}_{2}^{-}$was measured by monitoring the SOD-sensitive reduction of ferricytochrome C. $* p<0.05$ vs normal D-glucose conditions (i.e. $5 \mathrm{mmol} / \mathrm{l} \mathrm{D}$-glucose, $n=6-9)$

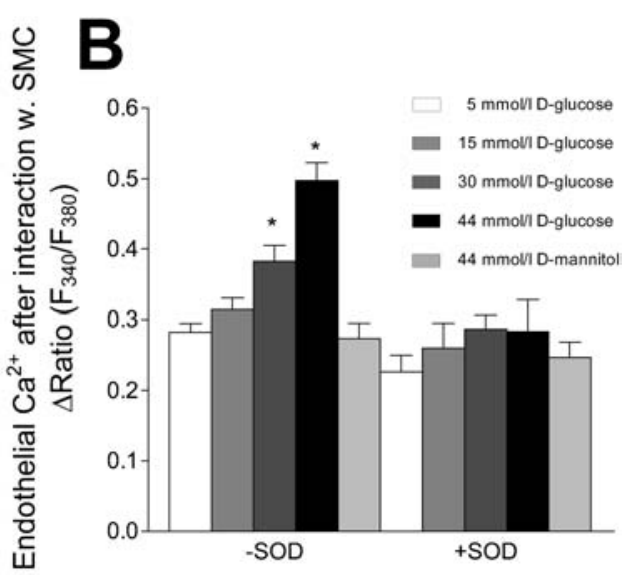

result in altered endothelial $\mathrm{Ca}^{2+}$ signalling after cell interaction (Fig. 2B). Changes in endothelial $\mathrm{Ca}^{2+}$ signalling by interaction with high $\mathrm{D}$-glucose preexposed SMC represented a time-dependent phenomenon that started after 30 min and peaked after $4 \mathrm{~h}$ of interaction (data not shown). Moreover, interaction of EC with high D-glucose pre-exposed SMC $10 \mathrm{~h}$ after high D-glucose was removed from the SMC, did not affect endothelial $\mathrm{Ca}^{2+}$ signalling (data not shown).

If $200 \mathrm{U} / \mathrm{ml} \mathrm{SOD}$ was present during the 4-h interaction between EC and high D-glucose pre-exposed SMC endothelial $\mathrm{Ca}^{2+}$ signalling was normalized (Fig. 2B) while $500 \mathrm{U} / \mathrm{ml}$ catalase during interaction could not prevent alterations in endothelial $\mathrm{Ca}^{2+}$ signalling by high D-glucose pre-exposed SMC. If EC were exposed for $4 \mathrm{~h}$ to DMEM that was preconditioned for $6 \mathrm{~h}$ by SMC, which were pre-treated for $24 \mathrm{~h}$ under hyperglycaemic conditions, only a small increase in endothelial $\mathrm{Ca}^{2+}$ signalling was detectable (data not shown).

Release of $\cdot \mathrm{O}_{2}^{-}$from smooth muscle cells in response to elevated D-glucose. Preincubation of SMC in medium with elevated D-glucose concentration increased the release of $\mathrm{O}_{2}$ - in a concentration-dependent manner (Fig. 3). In contrast, incubation of SMC in DMEM containing $44 \mathrm{mmol} / \mathrm{l} \mathrm{D}$-mannitol did not affect their $\mathrm{O}_{2}-$ release (Fig. 3).

Changes in endothelial cell cytoskeleton arrangement by SMC-derived radicals. In EC that were exposed for $4 \mathrm{~h}$ to high D-glucose pre-exposed SMC strong f-actin polymerization was observed (Fig. 4). This effect was prevented when SOD $(200 \mathrm{U} / \mathrm{ml})$ was present during the 4-h interaction. In line with these findings, exposure of EC for $1 \mathrm{~h}$ to DMEM containing the $\mathrm{O}_{2}^{-}$ generating mixture of $1 \mathrm{mmol} / \mathrm{l}$ hypoxanthine and $300 \mu \mathrm{U} / \mathrm{ml}$ xanthine oxidase yielded SOD-sensitive $(200 \mathrm{U} / \mathrm{ml})$ but catalase-insensitive $(500 \mathrm{U} / \mathrm{ml})$ stress fibre formation (data not shown).

Effect of intercellular signalling on endothelial transcription factor activation. To verify additional effects 

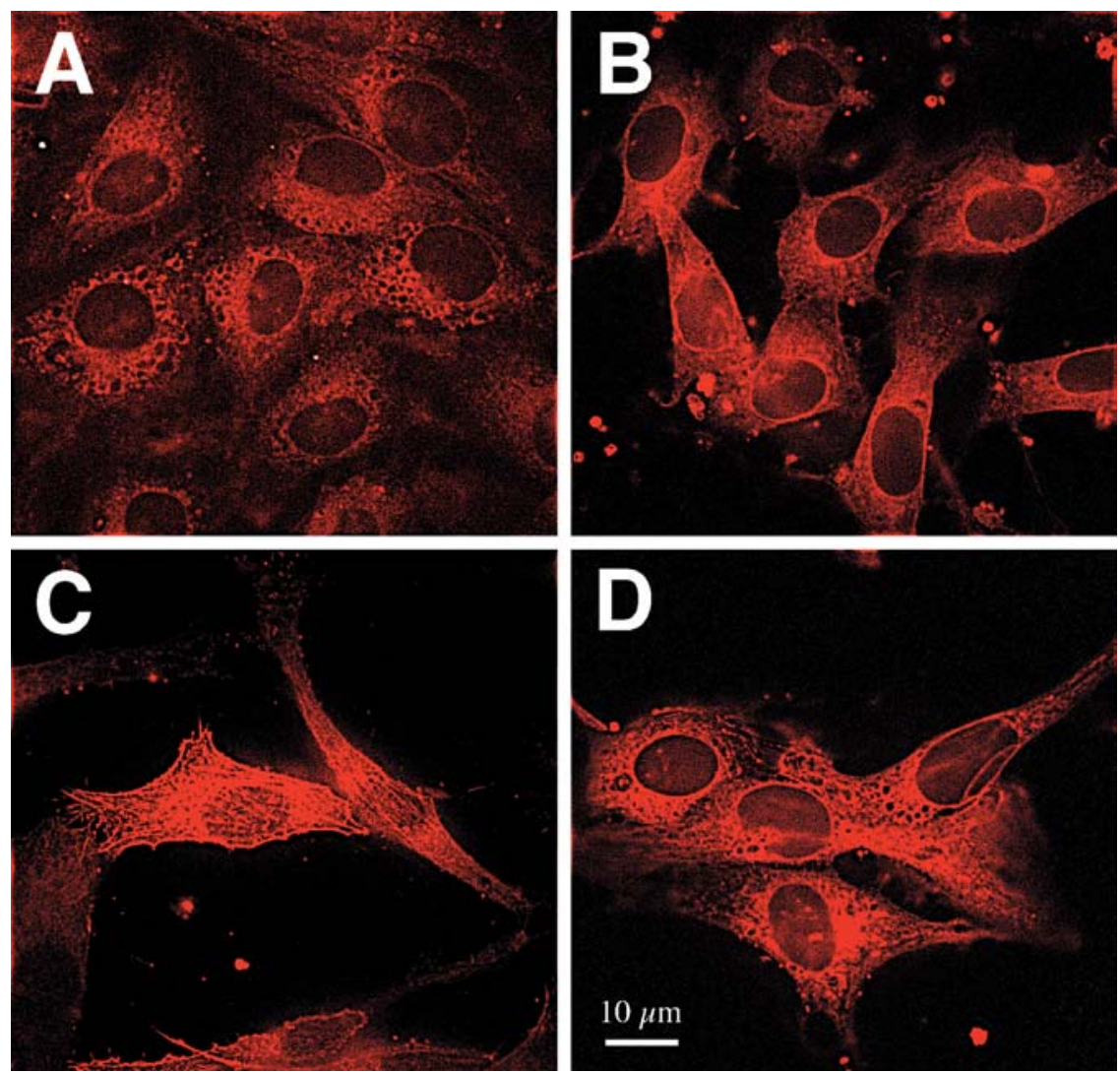

Fig. 4A-D. The interaction of endothelial cells with hyperglycemia-preexposed SMC alters endothelial cytoskeleton organization in an SOD-sensitive manner. EC were put for $4 \mathrm{~h}$ in DMEM on top of SMC that were pretreated for $24 \mathrm{~h}$ in DMEM containing 5 (A and B) or $44 \mathrm{mmol} / \mathrm{l}(\mathbf{C}$ and $\mathbf{D})$ D-glucose in the absence (A and $\mathbf{C}$ ) or presence (B and $\mathbf{D})$ of $200 \mathrm{U} / \mathrm{ml}$ SOD. EC were fixed and f-actin was stained using Bodipy $581 / 591$ phalloidine. Fluorescence was monitored at $584 \mathrm{~nm}$ excitation and 630 emission using a deconvolution fluorescence microscope as described previously [6] $(n=15)$

of interaction of EC with high D-glucose pre-exposed SMC, endothelial NFKB activation was studied using EMSA. Interaction of EC for $4 \mathrm{~h}$ with untreated (lane 1) as well as high D-glucose pre-exposed SMC (lane 2) slightly activated endothelial NFKB as compared to EC that did not interact with SMC (lane 8). Nevertheless, no differences in NFKB activation were found between EC that could interact with untreated or high D-glucose pre-exposed SMC. In contrast, in the presence of SOD $(200 \mathrm{U} / \mathrm{ml}) \mathrm{NF \kappa B}$ activation occurred in cells that were incubated with high D-glucose pre-exposed SMC (lane 4) but not in cells that interfered with untreated SMC (lane 3) (Fig. 5).

The $\mathrm{O}_{2}^{-}$-generating mixture of $1 \mathrm{mmol} / \mathrm{l}$ hypoxanthine and $300 \mu \mathrm{U} / \mathrm{ml}$ xanthine oxidase only slightly stimulated NFKB (lane 5) while in the presence of SOD $(200 \mathrm{U} / \mathrm{ml})$ this effect was more pronounced (lane 6). Hydrogen peroxide $\left(\mathrm{H}_{2} \mathrm{O}_{2} ; 10 \mu \mathrm{mol} / \mathrm{l}\right)$ also caused strong NFKB stimulation (lane 7) that was prevented by catalase $(500 \mathrm{U} / \mathrm{ml}$; data not shown).

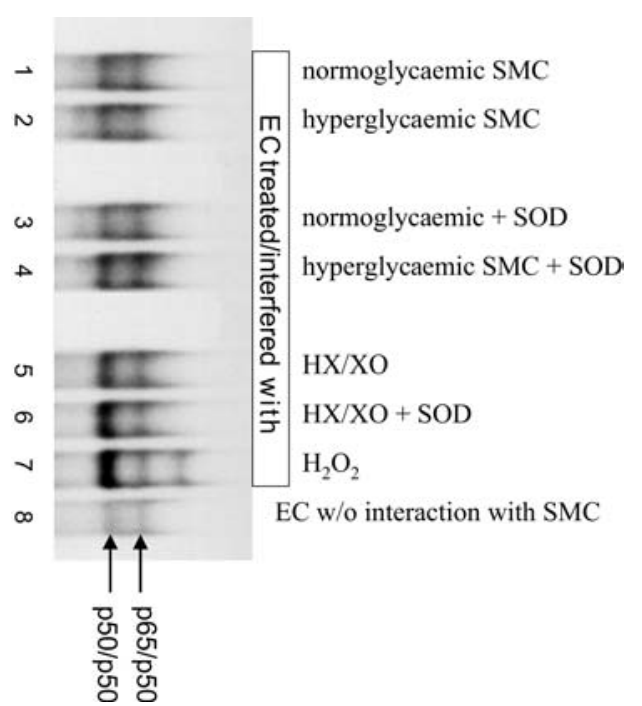

Fig. 5. The interaction of EC with high D-glucose pre-exposed SMC does not indicate activation of endothelial NFKB. Representative analysis on the dimerization of the p65 and the p50 subunits for NFKB stimulation by EMSA in EC. EC were incubated for $4 \mathrm{~h}$ in DMEM with SMC that were pretreated for $24 \mathrm{~h}$ in DMEM containing 5 (lane 1) or $44 \mathrm{mmol} / \mathrm{l}$ (lane 2) D-glucose or in DMEM containing $200 \mathrm{U} / \mathrm{ml} \mathrm{SOD}$ and 5 (lane 3) or $44 \mathrm{mmol} / \mathrm{l} \mathrm{D}$-glucose (lane 4). Alternatively, EC were treated for $1 \mathrm{~h}$ with $1 \mathrm{mmol} / \mathrm{l}$ hypoxanthine and $300 \mu \mathrm{U} / \mathrm{ml}$ xanthine oxidase in the absence (lane 5) or in the presence of SOD (lane 6). Lane 7 shows $\mathrm{NF \kappa B}$ activation in EC treated for $1 \mathrm{~h}$ with $10 \mu \mathrm{mol} / \mathrm{l}$ hydrogen peroxide $\left(\mathrm{H}_{2} \mathrm{O}_{2}\right)$. Lane 8 represents $\mathrm{NF \kappa B}$ in endothelial cells after $4 \mathrm{~h}$ in DMEM ( $5 \mathrm{mmol} / \mathrm{l} \mathrm{D}$-glucose) without any further treatment 

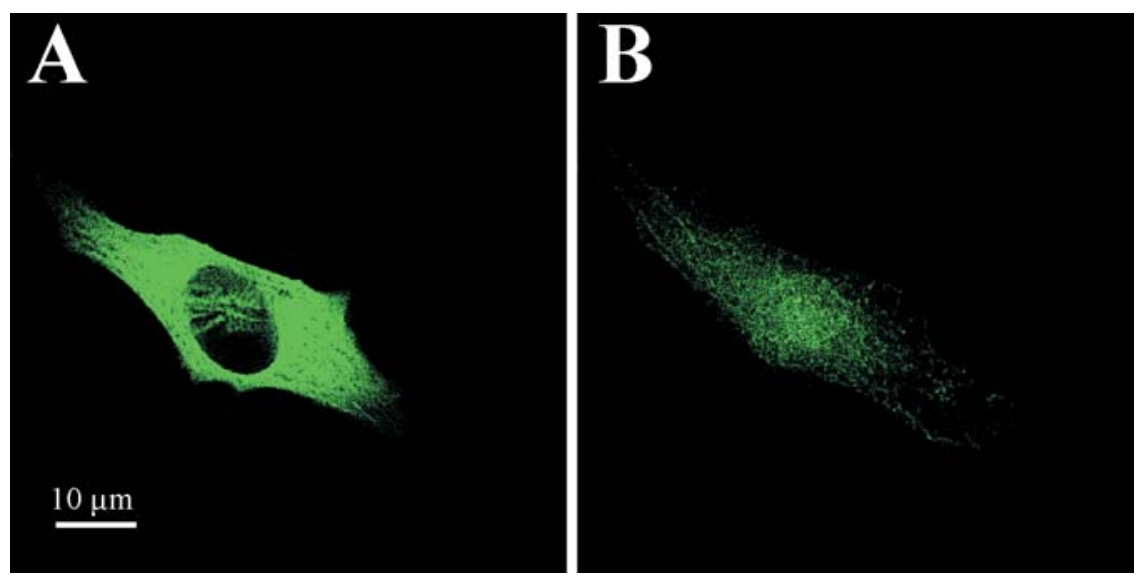

Fig. 6A, B. The nuclear translocation of p65-GFP during interaction with high D-glucose-pre-exposed SMC requires the presence of SOD. EC were transfected with the p65-GFP construct and after two days cells were put on top of SMC that were preincubated for $24 \mathrm{~h}$ in DMEM containing $44 \mathrm{mmol} / \mathrm{l}$ D-glucose. No nuclear translocation was found within $2 \mathrm{~h}$ of interaction in DMEM (5 mmol/l D-glucose) (A), while $45 \mathrm{~min}$ after addition of $200 \mathrm{U} / \mathrm{ml}$ SOD a clear nuclear translocation of p65-PFP was observed $(n=5)(\mathbf{B})$

In line with these findings, no nuclear translocation of $\mathrm{NF \kappa B}$ was observed in EC that interacted with high D-glucose pre-exposed SMC (Fig. 6A). However, if $200 \mathrm{U} / \mathrm{ml} \mathrm{SOD}$ were present a NFKB translocation to the nucleus occurred (Fig. 6B).

Similar to our findings on NFKB, endothelial AP-1 expression was not augmented by incubation with either untreated or high D-glucose pre-exposed SMC (Fig. 7), while in the presence of SOD $(200 \mathrm{U} / \mathrm{ml})$ an upregulation of AP-1 occurred. The expression of AP-1 initiated by the $\mathrm{O}_{2}^{-}$-generating mixture of hypoxanthine $(1 \mathrm{mmol} / \mathrm{l})$ and xanthine oxidase $(300 \mu \mathrm{U} / \mathrm{ml})$ was increased in the presence of SOD $(200 \mathrm{U} / \mathrm{ml})$. TNF $\alpha(10 \mathrm{ng} / \mathrm{ml})$ and $\mathrm{H}_{2} \mathrm{O}_{2}(10 \mu \mathrm{mol} / \mathrm{l})$ also yielded strong AP-1 activation (Fig. 7).

Effect of intercellular signalling on endothelial tyrosine kinase activity. We have shown that exposure of $\mathrm{EC}$ to the $\mathrm{O}_{2}^{-}$-generating mixture of hypoxanthine/xanthine oxidase results in activation of tyrosine kinase(s). To test whether $\mathrm{O}_{2}^{-}$derived from high $\mathrm{D}$ glucose pre-exposed SMC are responsible for tyrosine phosphorylation in EC, tyrosine kinase activity was monitored in EC homogenates after interaction with untreated and high D-glucose pre-exposed SMC. In $\mathrm{EC}$ that interacted for $4 \mathrm{~h}$ with high D-glucose pre-exposed SMC tyrosine kinase activity increased depending on the amount of D-glucose to which the SMC had been exposed to (Fig. 8A). Co-incubation with SOD $(200 \mathrm{U} / \mathrm{ml})$ during interaction with high D-glucose pre-exposed SMC prevented the increase in tyrosine kinase activity in EC. Furthermore, tyrosine phosphorylation of the cytoskeleton anchor protein

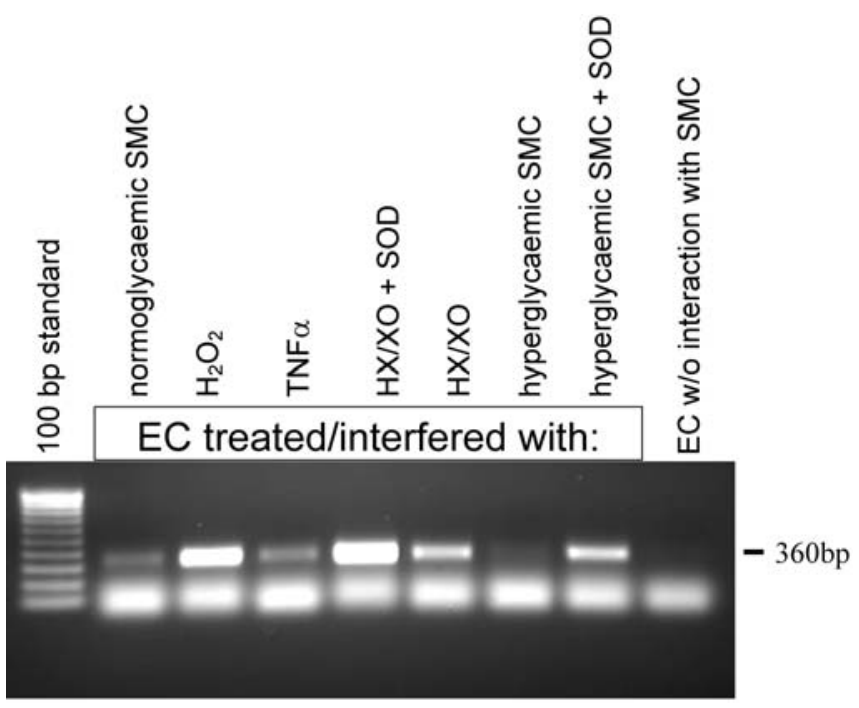

Fig. 7. Interaction of EC with high D-glucose-pre-exposed SMC does not enhance expression of AP-1. Representative RT-PCR analysis of AP-1 expression in EC without any treatment (EC w/o interaction with SMC), $10 \mu \mathrm{mol} / \mathrm{l}$ hydrogen peroxide $\left(\mathrm{H}_{2} \mathrm{O}_{2}\right), 10 \mathrm{ng} / \mathrm{ml} \mathrm{TNF} \alpha$, hypoxanthine/xanthine oxidase ( $1 \mathrm{mmol} / \mathrm{l}, 300 \mu \mathrm{U} / \mathrm{ml} ; \mathrm{HX} / \mathrm{XO}$ ) in the presence or absence of $200 \mathrm{U} / \mathrm{ml} \mathrm{SOD}$ (4 h each). In addition, EC were incubated for $4 \mathrm{~h}$ in DMEM ( $5 \mathrm{mmol} / \mathrm{l} \mathrm{D}$-glucose) with SMC that were pretreated for $24 \mathrm{~h}$ in DMEM containing 5 (normoglycaemic $\mathrm{SMC}$ ), $44 \mathrm{mmol} / \mathrm{l}$ D-glucose (hyperglycaemic SMC) or $44 \mathrm{mmol} / \mathrm{l} \mathrm{D}$-glucose plus $200 \mathrm{U} / \mathrm{ml}$ SOD (hyperglycaemic $\mathrm{SMC}+\mathrm{SOD})$

$\beta$-catenin was increased after interaction with high D-glucose pre-exposed SMC in a SOD-sensitive manner (Fig. 8B). In line with these findings, incubation of EC with exogenously generated $\mathrm{O}_{2}{ }^{-}$(hypoxanthine/xanthine oxidase; $1 \mathrm{mmol} / \mathrm{l}$ and $300 \mu \mathrm{U} / \mathrm{ml}$ ) for $4 \mathrm{~h}$ also resulted in tyrosine phosphorylation of $\beta$-catenin (data not shown).

This result was further confirmed when tyrosine kinase activation in response to exogenous $\mathrm{O}_{2}{ }^{-}$(hypoxanthine/xanthine oxidase; $1 \mathrm{mmol} / \mathrm{l}$ and $500 \mu \mathrm{U} / \mathrm{ml}$ ) was investigated in single EC using the fluorescence probe for tyrosine kinase activity Picchu-936X. Tyrosine phosphorylation increased predominantly on the edge of the cell within $30 \mathrm{~min}$ of $\mathrm{O}_{2}{ }^{-}$exposure, while 


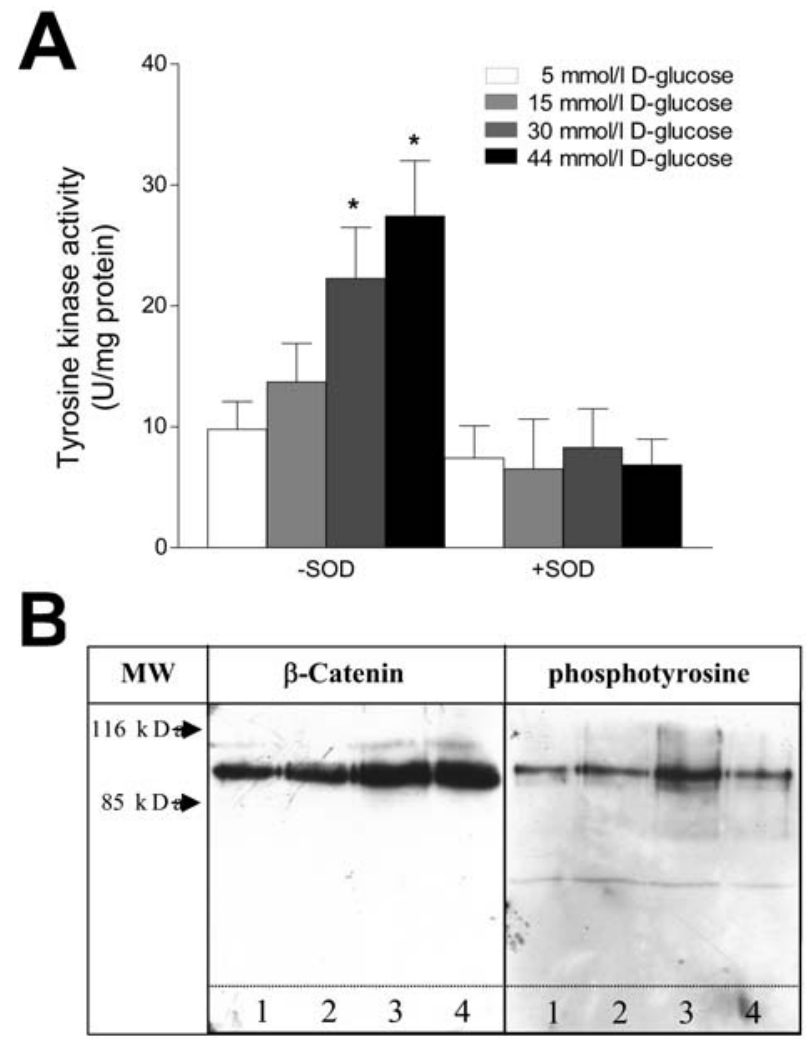

Fig. 8A, B. Interaction of EC with high D-glucose-pre-exposed SMC results in tyrosine kinase activation and tyrosine phosphorylation of $\beta$-catenin in a SOD-sensitive manner. (A) EC were put for $4 \mathrm{~h}$ in DMEM in the absence (-SOD) or presence of $200 \mathrm{U} / \mathrm{ml} \mathrm{SOD} \mathrm{(+SOD)} \mathrm{on} \mathrm{top} \mathrm{of} \mathrm{SMC} \mathrm{that} \mathrm{were} \mathrm{pre-}$ treated for $24 \mathrm{~h}$ in DMEM containing the D-glucose concentration indicated. Tyrosine kinase activity was monitored $(n=6)$. ${ }^{*} p<0.05$ vs kinase activity in cells after interaction with normoglycaemic SMC. (B) Western blot analysis $(n=3)$ of EC that were incubated in DMEM in the absence (lane 1 and 3 ) and presence of $200 \mathrm{U} / \mathrm{ml} \mathrm{SOD} \mathrm{(lane} 2$ and 4) with SMC pretreated for $24 \mathrm{~h}$ in DMEM containing 5 (lane 1 and 2) or $44 \mathrm{mmol} / \mathrm{l}$ D-glucose (lane 3 and 4). The same blot was labelled with anti-phosphotyrosine (right), stripped and reprobed with anti$\beta$-catenin (left)

no effect of hypoxanthine/xanthine oxidase on the inactive mutant Picchu-938X was found (data not shown).

Contribution of tyrosine kinase(s) to endothelial cell adaptation upon interaction with high D-glucose preexposed smooth muscle cells. To test which tyrosine kinase is involved in the changes of endothelial $\mathrm{Ca}^{2+}$ signalling upon interaction with high $\mathrm{D}$-glucose preexposed SMC, the non-specific tyrosine kinase inhibitors erbstatin analog $(10 \mu \mathrm{mol} / \mathrm{l})$, herbimycin A $(2 \mu \mathrm{mol} / \mathrm{l})$ and the src-family specific inhibitor PP-1 $(10 \mu \mathrm{mol} / \mathrm{l})$ were used. All inhibitors prevented changes in $\mathrm{Ca}^{2+}$ signalling in EC that interacted with high D-glucose pre-exposed SMC (Fig. 9). Furthermore, all tyrosine kinase inhibitors but not the protein kinase $\mathrm{C}$ inhibitor GF109203X (5 $\mu \mathrm{mol} / \mathrm{l})$ prevented stress fibre

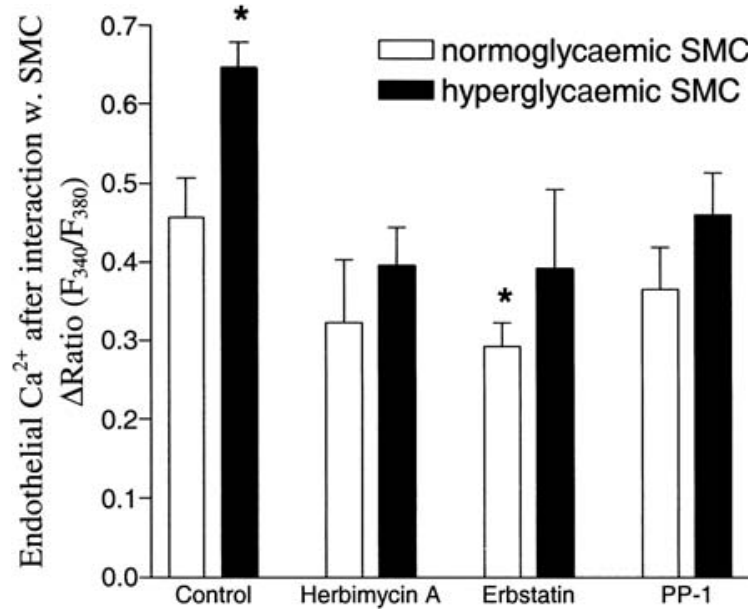

Fig. 9. Inhibition of tyrosine kinase(s) prevents alteration of endothelial $\mathrm{Ca}^{2+}$ signalling upon interaction with high D-glucose-pre-exposed SMC. EC were incubated with SMC that were pretreated for $24 \mathrm{~h}$ in DMEM containing 5 (normoglycaemic SMC) or $44 \mathrm{mmol} / \mathrm{l} \mathrm{D}$-glucose (hyperglycaemic $\mathrm{SMC}$ ) for $4 \mathrm{~h}$ in the absence (Control) or presence of either herbimycin A $(2 \mu \mathrm{mol} / \mathrm{l})$, erbstatin analog (Erbstatin, $10 \mu \mathrm{mol} / \mathrm{l})$ or PP-1 $(10 \mu \mathrm{mol} / \mathrm{l})$. Columns indicate the mean \pm SEM of the increase in cytosolic $\mathrm{Ca}^{2+}$ concentration in response to $100 \mathrm{nmol} / \mathrm{l}$ bradykinin in the presence of $2.5 \mathrm{mmol} / \mathrm{l}$ extracellular $\mathrm{Ca}^{2+}$. ${ }^{*} p<0.05$ vs endothelial $\mathrm{Ca}^{2+}$ signalling in cells after interaction with normoglycaemic SMC $(n=12)$

formation in EC exposed to high D-glucose-pretreated SMC (data not shown).

To further elucidate the involvement of c-src kinase in the observed changes in EC upon interaction with high D-glucose pre-exposed SMC, a kinase-inactive c-src (KI-src) was expressed in EC by infection with adenovirus encoding KI-src. As a control, EC were infected with adenovirus encoding LacZ. Expression of KI-src per se did not affect $\mathrm{Ca}^{2+}$ signalling but prevented the stimulatory effect of interaction with high D-glucose pre-exposed SMC (Fig. 10). In contrast, in EC that were infected with the control virus (i.e. LacZ) a similar enhancement of the $\mathrm{Ca}^{2+}$ signalling by high D-glucose pre-exposed SMC as in non-infected cells was observed (Fig. 10).

In agreement with our findings on $\mathrm{Ca}^{2+}$ signalling, formation of stress fibres in EC by interaction with high D-glucose pre-exposed SMC was prevented in cells transfected with KI-src but not in the respective control cells (Fig. 11).

\section{Discussion}

We have shown that SMC, which were exposed to elevated D-glucose concentration affect $\mathrm{EC}$ by the release of a diffusible factor that could be scavenged by $\mathrm{SOD}$, thus pointing to $\mathrm{O}_{2}^{-}$as paracrine molecules. While no activation of NFKB and AP-1 was found in 


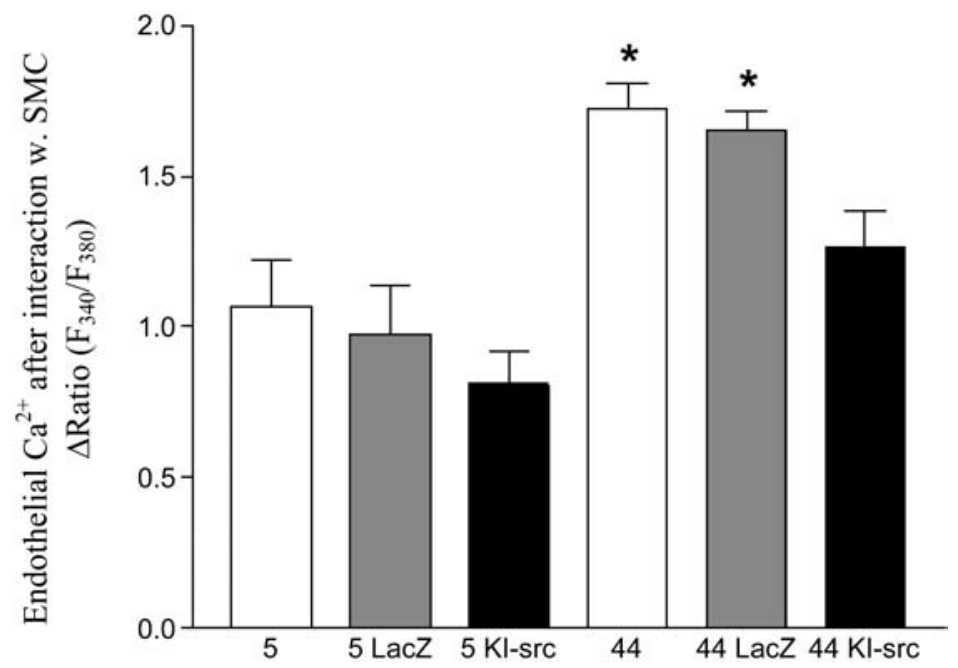

Fig. 10. Adenovirus-mediated transfection of EC with a kinase-inactive c-src but not LacZ prevents changes in endothelial $\mathrm{Ca}^{2+}$ signalling by high D-glucose-pre-exposed SMC. EC were infected with 1000 m.o.i. of adenovirus encoding kinase-inactive src $(K I-s r c)$ or LacZ. After 5 days the cells were incubated for $4 \mathrm{~h}$ in DMEM with SMC that were pretreated for $24 \mathrm{~h}$ in DMEM containing 5 or $44 \mathrm{mmol} / \mathrm{l} \mathrm{D}$-glucose. $* p<0.05$ vs EC incubated with normoglycaemic SMC $(n=6)$
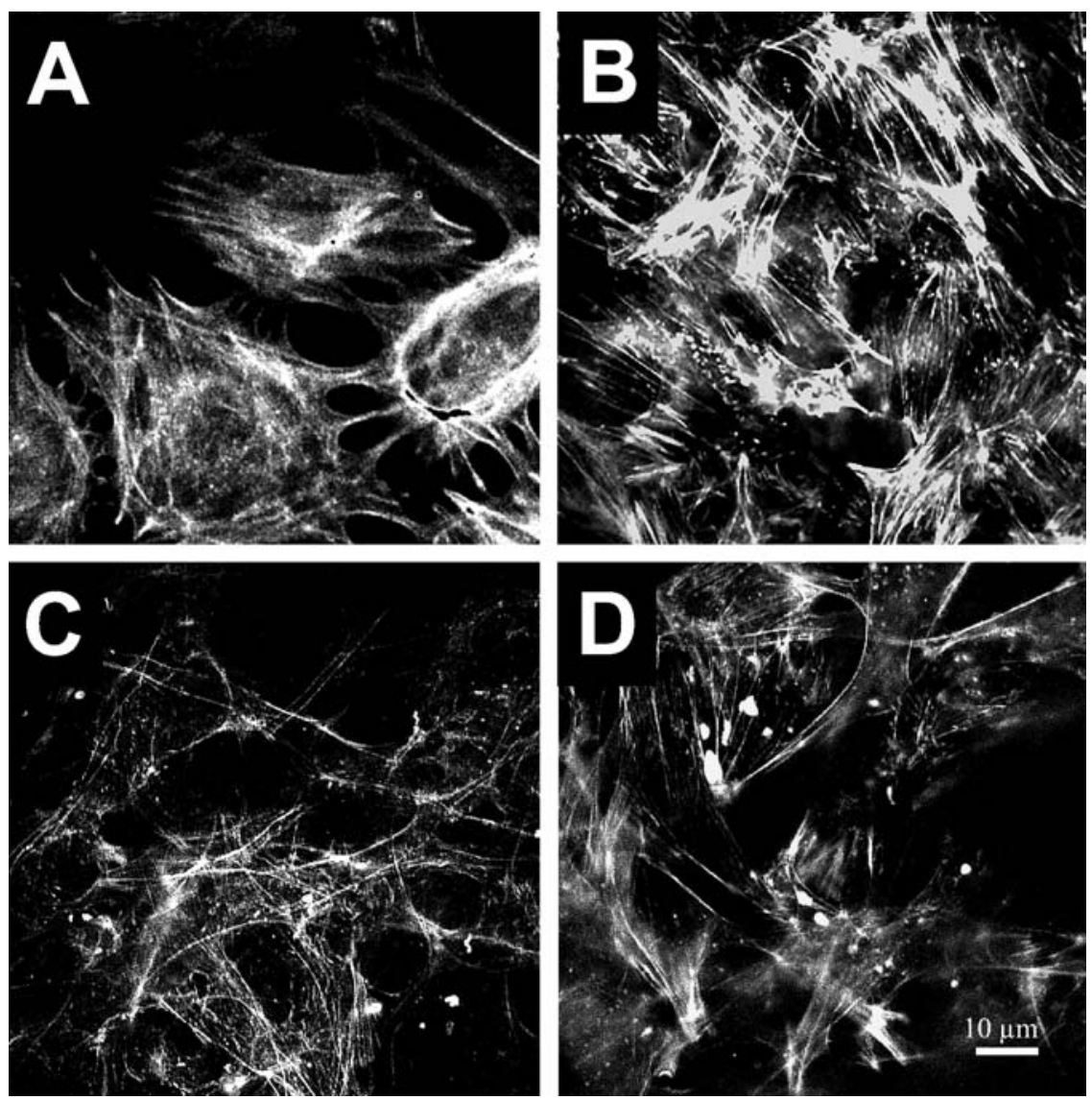

Fig. 11A-D. Adenovirus-mediated transfection of EC with a kinase-inactive c-src prevents changes in endothelial cytoskeleton organization by high D-glucose-pre-exposed SMC. EC were infected with 1000 m.o.i. of adenovirus encoding kinaseinactive c-src $(\mathbf{C}, \mathbf{D})$. After 5 days the cells were incubated for $4 \mathrm{~h}$ in DMEM with SMC that were pretreated for $24 \mathrm{~h}$ in DMEM containing $5(\mathbf{A}, \mathbf{C})$ or $44 \mathrm{mmol} / \mathrm{l}$ D-glucose $(\mathbf{B}, \mathbf{D})$

the absence of SOD, a stimulation of endothelial src kinase occurred, that in turn, resulted in reorganization of the cytoskeleton and alterations in $\mathrm{Ca}^{2+}$ signalling. These data suggest, that elevated D-glucose not only affects EC directly, but initiates the release of diffusible radicals from smooth muscle cells that, in turn, alter endothelial function via activation of the tyrosine kinase src. 
The intercellular signalling between SMC that were pre-treated with high D-glucose for $24 \mathrm{~h}$ and EC was initially shown by studying endothelial $\mathrm{Ca}^{2+}$ signalling. Notably, endothelial $\mathrm{Ca}^{2+}$ signalling has been shown to be a suitable marker for cell dysfunction initiated by a variety of stimuli such as E. coli lipopolysaccharides (LPS; [19]), peroxides [20, 21, 22], oxidized low density lipoprotein [23], streptozotocininduced diabetes $[24,25]$ and hyperglycaemia $[10,11$, 26]. The latter was causally linked to generation of $\mathrm{O}_{2}-$ in EC $[10,27]$. In line with these reports, the interaction of EC with high D-glucose pre-exposed SMC augmented the increase in cytosolic $\mathrm{Ca}^{2+}$ in response to bradykinin. As the magnitude of this effect correlated with the concentration of D-glucose the SMC had been exposed to, we suggest that D-glucose treatment of the SMC triggers the release of an intercellular signalling molecule in a concentration-dependent manner. The release of this paracrine molecule continues even after removal of the D-glucose excess and, in turn, alters endothelial $\mathrm{Ca}^{2+}$ signalling. However, high D-glucose pre-exposed $S M C$ that were kept for further $10 \mathrm{~h}$ under normoglycaemic conditions did not influence endothelial $\mathrm{Ca}^{2+}$ homeostasis. These data suggest that D-glucose-triggered release of signalling molecules from the SMC is reversible. Furthermore, pretreatment of the SMC with high concentrations of D-mannitol had no effect on endothelial $\mathrm{Ca}^{2+}$ signalling excluding hyperosmolarity as the cause for SMC activation. Thus, we wanted to find out which signalling molecule is released from the SMC that affects EC function.

Based on our recent observation of an increased $\mathrm{O}_{2}^{-}$production in SMC under diabetic [6] and hyperglycaemic conditions [28], the role of $\mathrm{O}_{2}{ }^{-}$as a prime candidate was studied by adding SOD during cell interaction. The result that SOD treatment abrogated the stimulatory effect of high D-glucose pre-exposed SMC on endothelial $\mathrm{Ca}^{2+}$ signalling strongly supports this hypothesis. This was further corroborated by the observation that $\mathrm{SMC}$ released $\mathrm{O}_{2}{ }^{-}$if treated with increased D-glucose (but not mannitol) in a concentration-dependent manner. Moreover, D-glucose-dependent $\mathrm{O}_{2}^{-}$release from porcine aortic $\mathrm{SMC}$ is in line with our previous report that the release of $\mathrm{O}_{2}{ }^{-}$is enhanced in uterine arteries of diabetic patients [6]. The source of SMC $\mathrm{O}_{2}{ }^{-}$and the mechanisms of its release under elevated D-glucose conditions are still a matter of debate, but NAD(P)H oxidase [29, 30, 31, 32, 33] and mitochondria $[34,35]$ have been discussed frequently to contribute to increased $\mathrm{O}_{2}^{-}$production in diabetes [7]. Overall, recent literature and our present data suggest that under hyperglycaemic conditions $\mathrm{O}_{2}^{-}$release from SMC is augmented and affects EC function.

This notion is further supported by our data on stress fibre formation in EC exposed to high D-glucose-pre-treated SMC, a phenomenon that could be prevented by SOD. Notably, the cytoskeleton and in particular f-actin bundles have been shown to contribute to $\mathrm{Ca}^{2+}$ signalling $[36,37,38,39]$. Thus, it is tempting to speculate that the observed effect on $\mathrm{Ca}^{2+}$ signalling is causally linked to alteration of the cytoskeleton. A reorganization of the cytoskeleton in vascular cells by free radicals has been reported presumably due to activation of the Rho GTPase family member Rac [40, 41, 42, 43, 7] that, in turn, triggers activation of the transcription factor NFKB [44]. In addition to NFkB, AP-1 was found to be activated by peroxides in human microvascular EC [45]. In line with these findings, we observed activation of $\mathrm{NF \kappa B}$ and upregulation of AP-1 in EC upon interaction with the high D-glucose pre-exposed SMC only in the presence of SOD which converts the SMC-derived $\mathrm{O}_{2}{ }^{-}$ to $\mathrm{H}_{2} \mathrm{O}_{2}$. Moreover, hypoxanthine/xanthine oxidase, a predominantly $\mathrm{O}_{2}{ }^{-}$generating system [46], had only minor effects on the activity of these two transcription factors. These data point to diversity in the effects of $\mathrm{H}_{2} \mathrm{O}_{2}$ and $\mathrm{O}_{2}^{-}$on regulation of the inflammatory transcription factors NFKB and AP-1 in EC.

In contrast, the interaction of EC with high D-glucose pre-exposed SMC resulted in activation of tyrosine kinase(s) that was dependent on the concentration of D-glucose used. Since co-incubation with SOD prevented endothelial tyrosine kinase(s) activation, one may assume that this $\mathrm{O}_{2}^{-}$-dependent tyrosine kinase(s) activation is crucial for modulation of endothelial function by high D-glucose pre-exposed SMC. This hypothesis is further confirmed by our finding of a SOD-sensitive tyrosine phosphorylation of the cytoskeleton anchor protein $\beta$-catenin in EC by high D-glucose pre-treated SMC. Moreover, activation of endothelial tyrosine kinase(s) by extracellullar $\mathrm{O}_{2}^{-}$ was further shown in single cells using Picchu-936X, a recently introduced molecular sensor for tyrosine kinase activity [17].

Besides the wide range tyrosine kinase inhibitors erbstatin analog and herbimycin A [47], the rather selective src family inhibitor PP-1 [48] prevented the above mentioned changes in EC function upon interaction with high D-glucose pre-exposed SMC thus, pointing to an involvement of src family member(s) therein. This assumption was further supported by the findings that transfection of EC with dominant negative c-src kinase diminished the observed changes in $\mathrm{Ca}^{2+}$ signalling and stress fibre formation. These data suggest that $\mathrm{O}_{2}-$ derived from high $\mathrm{D}$-glucose preexposed SMC activate endothelial src kinase that, in turn, alters cytoskeleton and $\mathrm{Ca}^{2+}$ signalling.

Our findings that the protein kinase $\mathrm{C}$ inhibitor GF109203X [49, 50] failed to prevent endothelial tyrosine kinase activation by high $\mathrm{D}$-glucose preexposed SMC suggest that an activation of protein kinase $\mathrm{C}$ is not involved in the activation of src by $\mathrm{O}_{2}-$. In consideration of the stimulation of protein kinase C- $\beta$ during hyperglycaemia [9], the tyrosine 
kinase activation reported herein represents a new pathway in diabetes. While the exact mechanism of src kinase activation is unclear, it seems obvious that extracellular $\mathrm{O}_{2}^{-}$but not $\mathrm{H}_{2} \mathrm{O}_{2}$ mediate this effect. Alternatively, increased tyrosine phosphorylation could be the result of inhibition of src selective tyrosine phosphatases as it was recently shown by $\mathrm{H}_{2} \mathrm{O}_{2}$ [51]. However, basal src kinase activity seemed to be rather low in the EC used, thus favouring the hypothesis that ${ }^{\circ}{ }_{2}^{-}$ derived from high D-glucose pre-exposed SMC activate endothelial src kinase by unknown mechanisms.

Since all reported phenomena (i.e. changes in $\mathrm{Ca}^{2+}$ signalling, tyrosine kinase activation and stress fibre formation) were sensitive to the presence of SOD within the interaction period and could further be mimicked by a direct treatment of endothelial cells with the $\mathrm{O}_{2}-$ generating mixture xanthine oxidase/hypoxanthine, we speculate that smooth muscle-derived $\mathrm{O}_{2}{ }^{-}$serve as intercellular messenger between the two types of vascular cells. However, our findings do not exclude additional signalling molecules like hsp 90 that was recently found to constitute a smooth muscle-derived messenger molecule under oxidative stress conditions [52].

Our data that SOD was actually prerequisite in order to initiate NFKB/AP-1 activation but prevented changes in $\mathrm{Ca}^{2+}$ signalling, src activation and stress fibre formation in EC by high D-glucose pre-exposed SMC point to two distinct pathways as potential targets under hyperglycaemic conditions. It is tempting to speculate that depending on the activity/expression of SOD in the vascular bed one or the other (or both) of the two signalling pathways gets activated under hyperglycaemic conditions. In view of the reported alterations of SOD expression during prolonged hyperglycaemic conditions $[7,53]$ it seems possible that the src pathway represents an initial target during acute hyperglycaemia while prolonged hyperglycaemia favours activation of the NFKB/AP-1 pathway. The actual consequences of such switch need to be further explored.

In conclusion, our data suggest that $\mathrm{O}_{2}^{-}$derived from hyperglycaemia pre-exposed SMC activate EC src kinase independently of protein kinase C. The enhanced tyrosine kinase activity initiates f-actin polymerization, phosphorylation of $\beta$-catenin and alters endothelial $\mathrm{Ca}^{2+}$ signalling. Our work unmasks considerable differences between the effects of $\mathrm{O}_{2}^{-}$and $\mathrm{H}_{2} \mathrm{O}_{2}$ on transcription factor activation and point to a surprising versatility in radical-mediated signal transduction.

Acknowledgements. We thank Dr. M. Okuda, University of Washington, WA, USA and Dr. B.C. Berk, University of Rochester, NY, USA for the virus construct and Dr. R. de Martin, University of Vienna, Austria, for the p65-GFP. The help of Mrs. K. Henning, MS K. Osibow and Dr. R. Malli is highly appreciated. MMS was supported by the Austrian Academy of Sciences. The authors thank Mr. G. Herzog (Gratwein, Austria) for providing the porcine tissue and his excellent tissue preparation. This work was supported by the Austrian Funds (SFB 714 and P-14586-PHA) and the Austrian National
Bank (P7542 and P7902). The Department of Medical Biochemistry \& Medical Molecular Biology is a member of the Institutes of Basic Medical Sciences (IBMS) at the University of Graz and was supported by the infrastructure program (UGP4) of the Austrian Ministry of Education, Science and Culture.

\section{References}

1. Cohen R (1993) Dysfunction of vascular endothelium in diabetes mellitus. Circulation 87 [Suppl V]:V67-V76

2. Kirpichnikov D, Sowers JR (2001) Diabetes mellitus and diabetes-associated vascular disease. Trends Endocrinol Metab 12:225-230

3. Schaeffer G, Wascher TC, Kostner GM, Graier WF (1999) Alterations in platelet $\mathrm{Ca}^{2+}$ signalling in diabetic patients is due to increased formation of superoxide anions and reduced nitric oxide production. Diabetologia 42:167-176

4. Srivastava AK, St-Louis J (1997) Smooth muscle contractility and protein tyrosine phosphorylation. Mol Cell Biochem 176:47-51

5. Srivastava AK (2002) High glucose-induced activation of protein kinase signaling pathways in vascular smooth muscle cells: a potential role in the pathogenesis of vascular dysfunction in diabetes. Int J Mol Med 9:85-89

6. Fleischhacker E, Esenabalu VE, Spitaler M, Holzmann S, Skrabal F, Koidl B, Kostner GM, Graier WF (1999) Human diabetes is associated with hyperreactivity of vascular smooth muscle cells due to altered subcellular $\mathrm{Ca}^{2+}$ distribution. Diabetes 48:1323-1330

7. Spitaler MM, Graier WF (2002) Vascular targets of redox signalling in diabetes mellitus. Diabetologia 45:476-494

8. Pieper GM (1998) Review of alterations in endothelial nitric oxide production in diabetes: protective role of arginine on endothelial dysfunction. Hypertension 31:1047-1060

9. Idris IG, Donnelly R (2001) Protein kinase C activation: isozyme-specific effects on metabolism and cardiovascular complications in diabetes. Diabetologia 44:659-673

10. Graier WF, Simecek S, Kukovetz WR, Kostner GM (1996) High-D-glucose-induced changes in endothelial $\mathrm{Ca}^{2+} / \mathrm{EDRF}$ signaling are due to generation of superoxide anions. Diabetes 45:1386-1395

11. Graier WF, Wascher TC, Lackner L, Toplak H, Krejs GJ, Kukovetz WR (1993) Exposure to elevated D-glucose concentrations modulates vascular endothelial cell vasodilatatory response. Diabetes 42:1497-1505

12. Graier WF, Hoebel BG, Paltauf-Doburzynska J, Kostner GM (1998) Effects of superoxide anions on endothelial $\mathrm{Ca}^{2+}$ signaling pathways. Arterioscler Thromb Vasc Biol 18:1470-1479

13. Steinbrecher UP (1988) Role of superoxide in endothelialcell modification of low-density lipoproteins. Biochim Biophys Acta 959:20-30

14. Frieden M, Malli R, Samardzija M, Demaurex N, Graier WF (2002) Subplasmalemmal endoplasmic reticulum controls $\mathrm{K}_{\mathrm{Ca}}$ channel activity upon stimulation with a moderate histamine concentration in a human umbilical vein endothelial cell line. J Physiol 540:73-84

15. Krzesz R, Wagner AH, Cattaruzza M, Hecker M (1999) Cytokine-inducible CD40 gene expression in vascular smooth muscle cells is mediated by nuclear factor kappaB and signal transducer and activation of transcription-1. FEBS Lett 453:191-196

16. Hoebel BG, Graier WF (1998) 11,12-Epoxyeicosatrienoic acid stimulates tyrosine kinase activity in porcine aortic endothelial cells. Eur J Pharmacol 346:115-117 
17. Kurokawa K, Mochizuki N, Ohba Y, Mizuno H, Miyawaki A, Matsuda M (2001) A pair of fluorescent resonance energy transfer-based probes for tyrosine phosphorylation of the CrkII adaptor protein in vivo. J Biol Chem 276:31305-31310

18. Okuda M, Takahashi M, Suero J et al. (1999) Shear stress stimulation of $\mathrm{p} 130$ (cas) tyrosine phosphorylation requires calcium-dependent c-Src activation. J Biol Chem 274:26803-26809

19. Graier WF, Myers PR, Adams HR, Parker JL (1994) E. coli endotoxin inhibits agonist-mediated cytosolic calcium mobilization and nitric oxide biosynthesis in cultured endothelial cells. Circ Res 75:659-668

20. Doan TN, Gentry DL, Taylor AA, Elliott SJ (1994) Hydrogen peroxide activates agonist-sensitive $\mathrm{Ca}^{2+}$-flux pathways in canine venous endothelial cells. Biochem J 297:209-215

21. Elliott SJ, Doan TN (1993) Oxidant stress inhibits the storedependent $\mathrm{Ca}^{2+}$-influx pathway of vascular endothelial cells. Biochem J 292:385-393

22. Koliwad SK, Kunze DL, Elliott SJ (1996) Oxidant stress activates a non-selective cation channel responsible for membrane depolarization in calf vascular endothelial cells. J Physiol 491:1-12

23. Zhao B, Ehringer WD, Dierichs R, Miller FN (1997) Oxidized low-density lipoprotein increases endothelial intracellular calcium and alters cytoskeletal f-actin distribution. Eur J Clin Invest 27:48-54

24. Kamata K, Sugiura M, Kasuya Y (1995) Decreased Ca ${ }^{2+}$ influx into the endothelium contributes to the decrease in endothelium-dependent relaxation in the aorta of streptozotocin-induced diabetic mice. Res Commun Mol Pathol Pharmacol 90:69-74

25. Kamata K, Nakajima M (1998) $\mathrm{Ca}^{2+}$ mobilization in the aortic endothelium in streptozotocin-induced diabetic and cholesterol-fed mice. Br J Pharmacol 123:1509-1516

26. Pieper GM, Dondlinger L (1997) Glucose elevations alter bradykinin-stimulated intracellular calcium accumulation in cultured endothelial cells. Cardiovasc Res 34:169-178

27. Graier WF, Posch K, Wascher TC, Kostner GM (1997) Role of superoxide anions in changes of endothelial vasoactive response during acute hyperglycemia. Horm Met Res 29:622-626

28. Graier WF, Posch K, Fleischhacker E, Wascher TC, Kostner GH (1999) Increased superoxide anion formation in endothelial cells during hyperglycemia: an adaptive response or initial step of vascular dysfunction? Diabet Res Clin Pract 45:153-160

29. Pagano PJ, Ito Y, Tornheim K, Gallop P, Tauber AI, Cohen RA (1995) An NADPH oxidase superoxide-generating system in the rabbit aorta. Am J Physiol 268:H2274$\mathrm{H} 2280$

30. Griendling KK, Alexander RW (1996) Endothelial control of the cardiovascular system: recent advances. Faseb J 10:283-292

31. Griendling KK, Sorescu D, Ushio-Fukai M (2000) $\mathrm{NAD}(\mathrm{P}) \mathrm{H}$ oxidase: role in cardiovascular biology and disease. Circ Res 86:494-501

32. Mohazzab KM, Wolin MS (1994) Sites of superoxide anion production detected by lucigenin in calf pulmonary artery smooth muscle. Am J Physiol 267:L815-L822

33. Mohazzab KM, Kaminski PM, Wolin MS (1994) NADH oxidoreductase is a major source of superoxide anion in bovine coronary artery endothelium. Am J Physiol 266:H2568-H2572

34. Nishikawa T, Edelstein D, Du XL et al. (2000) Normalizing mitochondrial superoxide production blocks three pathways of hyperglycaemic damage. Nature 404:787-790
35. Nishikawa T, Edelstein D, Brownlee M (2000) The missing link: a single unifying mechanism for diabetic complication. Kidney Int 58 [Suppl]77:26-30

36. Holda JR, Blatter A (1997) Capacitative calcium entry is inhibited in vascular endothelial cells by disruption of cytoskeletal microfilaments. FEBS Lett 403:191-196

37. Rosado JA, Sage SO (2000) The actin cytoskeleton in store-mediated calcium entry. J Physiol 526:221-229

38. Rosado JA, Jenner S, Sage SO (2000) A role for the actin cytoskeleton in the initiation and maintenance of storemediated calcium entry in human platelets. Evidence for conformational coupling. J Biol Chem 275:7527-7533

39. Wang YJ, Gregory RB, Barritt GJ (2002) Maintenance of the filamentous actin cytoskeleton is necessary for the activation of store-operated $\mathrm{Ca}^{2+}$ channels, but not other types of plasma-membrane $\mathrm{Ca}^{2+}$ channels, in rat hepatocytes. Biochem J 363:117-126

40. Sundaresan MY, Ferrans ZX, Sulciner VJ et al. (1996) Regulation of reactive-oxygen-species generation in fibroblasts by Rac1. Biochem J 318:379-382

41. Irani K, Xia Y, Zweier JL et al. (1997) Mitogenic signaling mediated by oxidants in Ras-transformed fibroblasts. Science 275:1649-1652

42. Irani K, Goldschmidt-Clermont PJ (1998) Ras, superoxide and signal transduction. Biochem Pharmacol 55:13391346

43. Irani K (2000) Oxidant signaling in vascular cell growth, death, and survival : a review of the roles of reactive oxygen species in smooth muscle and endothelial cell mitogenic and apoptotic signaling. Circ Res 87:179-183

44. Huttunen HJ, Fages C, Rauvala H (1999) Receptor for advanced glycation end products (RAGE)-mediated neurite outgrowth and activation of NF-kappaB require the cytoplasmic domain of the receptor but different downstream signaling pathways. J Biol Chem 274:19919-19924

45. Allen RG, Tresini M (2000) Oxidative stress and gene regulation. Free Radic Biol Med 28:463-499

46. Gilbert DA, Bergel F (1964) The chemistry of xanthine oxidase. 9. An improved method of preparing the bovine milk enzyme. Biochem J 90:350-353

47. Garcia R, Parikh NU, Saya H, Gallick GE (1991) Effect of herbimycin A on growth and pp60c-src activity in human colon tumor cell lines. Oncogene 6:1983-1989

48. Hanke JH, Gardner JP et al. (1996) Discovery of a novel, potent, and Src family-selective tyrosine kinase inhibitor. Study of Lck- and FynT-dependent T cell activation. J Biol Chem 271:695-701

49. Toullec D, Pianetti P, Coste H et al. (1991) The bisindolylmaleimide GF 109203X is a potent and selective inhibitor of protein kinase C. J Biol Chem 266:15771-15781

50. Inoguchi TL, Umeda P, Yu F et al.(2000) High glucose level and free fatty acid stimulate reactive oxygen species production through protein kinase $\mathrm{C}$-dependent activation of $\mathrm{NAD}(\mathrm{P}) \mathrm{H}$ oxidase in cultured vascular cells. Diabetes 49:1939-1945

51. Blanchetot C, Tertoolen LG, Hertog J den (2002) Regulation of receptor protein-tyrosine phosphatase alpha by oxidative stress. EMBO J 21:493-503

52. Liao DF, Jin ZG, Baas AS et al. (2000) Purification and identification of secreted oxidative stress-induced factors from vascular smooth muscle cells. J Biol Chem 275:189196

53. Ceriello A, Russo P dello, Amstad P, Cerutti P (1996) High glucose induces antioxidant enzymes in human endothelial cells in culture. Evidence linking hyperglycemia and oxidative stress. Diabetes 45:471-477 